\title{
TUTKIMUSTEMME LÄHTEISTÖ KAVENTUMASSA KOTIMAISEKSI JA ANGLOSAKSISEKSI
}

JYRI MANNINEN, ANTTI KAUPPI, ARJA PUURULA \& (toim.) (2003), Aikuiskasvatus tutkijoiden silmin - tutkimusta 2000-luvun taitteessa.

Kansanvalistusseura ja Aikuiskasvatuksen Tutkimusseura.

Kansanvalistusseura ja Aikuiskasvatuksen Tutkimusseura jatkavat ansiokasta alan tutkimusta esittelevien artikkelikirjojen sarjaansa nyt vuoden 2001 aikuiskasvatuksen tutkijatapaamisen keynoteista ja peer review'n läpäisseistä papereista kootulla teoksella. Mukaan on otettu seuraavat artikkelit:

- Risto Rinne, Arjen työn ja kulttuuristen merkitysten jäljillä. Haasteita 2000-luvun aikuiskoulutustutkimukselle,

- Anja Heikkinen, Kansainvälistä konsultointia vai poikkikulttuurista tutkimusyhteistyötä?

- Karin Filander, Kulttuurinen tutkimusote, kehittäjyys ja sukupuoli,

- Marjo Vuorikoski, Opettajan vaiettu valta. Alistamiskokemukset opettajaksi opiskelevien koulumuistoissa,

- Erja Moore, Aikuiset yliopisto-opiskelijat: elinikäistä oppia käytännössä,

- Hannele Kerosuo, Työtä kehittävä oppimisympäristö,

- Leena Ahteenmäki-Pelkonen, Ammattikorkeakoulujen orastava tutkimus- ja kehitystyö,

- Mika Tammilehto, Ammatillinen koulutus ja osaamisen alueellinen kehittäminen,

- Aino Jaatinen, Kuinka opettaa englantia ikäihmisille? Toimintatutkimus opettajan oman työn kehittämisen välineenä ja

- Tiina Kontinen, Kumppanuus oppimishaasteena. Näkökulma suomalaisten kansalaisjärjestöjen kehitysyhteistyöhön Morogorossa, Tansaniassa.

\section{TUTKIMUKSEN TILAN ARVIOINTIKRITEEREITÄ}

Tutkimuksen tilaa jollakin tieteenalalla - tässä tapauksessa aikuiskasvatustieteessä - esittelevää raporttia voidaan arvioida ainakin kolmella kriteerillä. 1. Kuinka kattavasti ja tarkasti se kuvaa tutkimuksen kentällä vallitsevan tilanteen, osoittaa sen painopistealueet ja huomaa ammottavat aukot kohdealueiden välillä (kuvauksen validiuskriteeri)?

2. Kuinka selkeästi se analysoi sovellettuja paradigmoja, oivaltaa niiden heikkoudet ja vahvuudet ja ohjaa paradigmojen muutosprosesseja (paradigmaattinen ohjauskriteeri)?

3. Kuinka jäsentyneesti se kokoaa tutkimuksen historian, visioi yhteiskunnan kehitysmahdollisuuksia avartavan tulevaisuudenvision, avaa käsillä olevat strategiset valinnat ja tekee ymmärrettäväksi niiden edellytyksiä ja todennäköisiä seuraamuksia (tutkimuspoliittinen kriteeri)?

Kuvauksen validiudesta toimittajat toteavat itse, että tavoitteena oli alun perin koota koko tutkijatapaamisen annin esittelevä konferenssiraportti. Varmaan kentän kuva olisi siten ollut vähemmän aukollinen kuin nyt, mutta tehty ratkaisu on kuitenkin lukijan kannalta parempi.
Parhaiden artikkeleiden julkaiseminen korostaa peer review'n tärkeyttä myös aikuiskasvatustieteen käytänteenä ja mukaan on näinkin saatu yllättävän monipuolinen joukko aikuiskoulutuksen kentän eri alueille kohdistuvia mielenkiintoisia tutkimuksia ja yleistarkasteluja.

Nostaisin tämän kriteerin suhteen esille Rinteen ja Heikkisen kansainväliltä näkökulmiltaan hyvin toisiaan täydentävät pohdiskelut sekä Tammilehdon ja Kontisen alueellista aspektia kotimaassa ja kehitysyhteistyössä korostavat työt. Kattavuutta voidaan tarkastella eri näkökulmista. Se on varsin hyvä kentän päälohkojen suhteen. Toimituskunta on pitänyt huolta siitä, että työelämä, ammatillinen koulutus, vapaa sivistystyö, opettajuus ja kansainväliset yhteydet ovat kukin saaneet kohtuullisen osuutensa. Aikuiskasvatustieteen osaalueet eivät ole aivan yhtä kattavasti edusteilla - ainakin kasvatusfilosofinen tutkimus on jäänyt satunnaisten mainintojen varaan ja yhteiskuntatieteellinen tutkimus dominoi psykologian ja didaktiikan kustannuksella. Osin tämä johtunee siitä, että verkkopedagogiikka on dominoinut didaktiikkaa ja sehän on tietenkin saanut viime vuosina eri yhteyksissä hyvin runsaasti tilaa, osin taas on myös kysymys ajankohdalle luonteenomaisesta tutkimusten jakaantumisesta osa-alueille.

KIELITAIDOSTAKO

MEILLÄ KIINNI?

Yhdessä suhteessa tieteen- 
alamme kuva on kirjan peilistä katsottuna todella masentava: esille tuodaan taas kerran lähes pelkästään kotimaisia ja anglosaksisista lähdekirjallisuutta. Eikö muka Pohjoismaissa tai muilla lähialueillamme, KeskiEuroopassa tai muissa maanosissa tehdä lainkaan sellaista tutkimusta, joka ansaitsisi tulla huomioon otetuksi (no, Baumanin, Bourdieun, Foucault'n ja Ziehen haamut sentään kummittelevat suomeksi, Alheitiin ja Freireen on viitattu englanniksi)? Kuva on varmaan melko oikea, mutta pelottavan kaksinapainen. Alamme tutkijoiden kielitaidon monipuolistamiseen on syytä panostaa, mikäli halutaan päästä muun kuin englantilaisen ja amerikkalaisen tiedon lähteille samaan aikaan kuin englanninkielisetkin. Pohjoismaisen tutkimusyhteistyön säilyttämiseen ja uudelleen virittämiseen olisi ilmeisesti myös syytä panostaa. Kentällä vaikutteita otetaan siltä suunnalta selvästi alttiimmin (esimerkiksi Nosto-ohjelma) kuin tutkimuksessa.

\section{PARADIGMA-ANALYYSI PUUTTUU}

Paradigmanmuutoksen pohdiskelu toteutuu kirjassa vain pieninä välähdyksinä. Siitä voi aavistaa, että alan yleistä kasvatustiedettä pidemmälle ehtinyt kvalitatiivistuminen ei ole (onneksi) johtanut minkään normaalitieteen vakiintumiseen. Vaihtoehdot eivät hahmotu ensisijaisesti paradigmojen kautta, vaikka artikkelien kirjoittajilla selvästi on vahva tietoisuus edustamastaan paradigmasta tai eklektisestä yhdistelmästä. Mukana on erilaisia lähestymistapoja, kehittävän työntutkimuksella on nyt selkeästi tun- nustettu asema (Kerosuon artikkeli, mukana myös Ahteenmäki-Pelkosella ja Kontisella), ajankohtaiset narratiiviset ja muut kulttuuriset tutkimusotteet tulevat myös esille useissa yhteyksissä. Filander käyttää (tosin pehmeästi) sukupuolinäkökulmaa mieskehittäjien ja naiskehittäjien puheiden vertailussa ja Vuorikoski tuo esille kriittiselle pedagogiikalle tyypillistä valtadynamiikkaa. Toisaalta: varsinaista paradigmakeskustelua ei kuitenkaan käydä, joten tulevaisuuteen suuntautuvan ohjauksen määrä jää puutteelliseksi.

\section{TUTKIMUSSTRATEGINEN VISIOINTI KALPEAA}

Tutkimuksen historia ja politiikka ovat kuitenkin kokoelman Akilleen kantapää. Teos on, osin antologialuonteensa vuoksi, pikakuva vallitsevasta tilanteesta. Juuria voi monista artikkeleista aavistella, mutta ainoa historiallis-poliittinen analyysi on Rinteen ja se kohdistuu enemmän aikuiskoulutukseen kuin sen tutkimiseen. Vaikka kaikki artikkelit jossain mielessä suuntautuvat myös tulevaisuuteen, se tapahtuu paljolti koulutusinstituutioiden kautta, kuten Ahteenmäki-Pelkosella ammattikorkeakoulujen tutkimuksellisten kehittämisnäkymien.

Tutkimusstrateginen ajattelu siinä mielessä, että visioitaisiin aikuiskasvatustieteen teorioiden rakentamista ja tiedon hallintaa, ei ollut vuosituhannen vaihteen Suomessa vielä kehittynyt, vaikka knowledge management onkin ollut 1990-luvun puolivälistä alkaen alan taikasanoja. Arvioni on, että kuvauskriteeri toteutuu parhaiten, paradigmakriteerin suhteen on jo toivomisen varaa ja keskustelua ajankohtaisista strategisista näkökohdista on aivan liian vähän. Kokonaisuutena tulos on kohtuullinen kirjaan, jonka toimittajat ovat olleet tutkijatapaamisen tarjonnan armoilla.

\section{AITO KUVA AIKAMME TUTKIMUKSESTA}

Aikuiskasvatus tutkijoiden silmin on mielenkiintoinen heijastus alan itsereflektiossa. Se ei ole tieteenfilosofiaa eikä kehittämisohjelma. Kuitenkin se antaa asiallisen ja rehellisentuntuisen kuvan tutkimuksesta, joka palvelee koulutuspoliittisesti hyvin merkitsevää kenttää.

Kokonaisuudessaan tämä tutkimus edelleen pikemminkin myötäilee kentällä toimivien uudistajien ja politiikan tekijöiden ideoita kuin luo systemaattisesti vahvaa tieteellistä pohjaa alueelle, joka on mullistamassa jo lähitulevaisuuden elinikäisesti oppivaa (ja viihtyvää) postmodernia elämysyhteiskuntaa enemmän kuin luonnontieteet ovat 1400-luvulta 1900-luvun loppuun mullistaneet valistuksen lumoissa vieläkin elävää modernia yhteiskuntaa ja sen koulutusnäkemyksiä. Tulevaisuus on toisenlainen, mutta sen toteuttamiseksi tarvitaan uusia tutkijatapaamisia ja niiden tuloksista tuotettavia teoksia. Paradigmakysymykset ja tutkimuskentän strateginen suunnittelu kannattaisi ainakin ottaa uusien tapaamisten aiheiksi.

Kari E. Nurmi 